\title{
原石とタリンカーの予備破砕
}

\section{小野 庸 二*}

突業机ける粉础作業は極めて重要な部門であって この部門の合理化改良々直ち飞製品コストに影響する あの大きいととは皆椂御承知の通りである。李た，粉 研のために消費される電力上鉄鋼の量ひ極めて龙大で あり，これが改善桠国家経済にも大きく影響すること 汇なる・したがって，各国の技術者がこれが改良に努 力して怙り, 近年粉砕作業は急速な進歩を遂げつつあ る。本日は粉砕作業の一部門である予備破砕につい て，主として私の会社が製作しているインペラーブレ 一カー年よる予借破确㶤ついて，若下の私見を述べて 皆樣の御批判を受けたい。

われわれは粉础工程を分類して，一次破础 (Primary crushing), 二次破碎 (Secondary crushing), 微 粉砕 (Grinding or Pulverising) の 3 種に区別してい る。一次破砕は原石山で行う破砕，あるいね場飞大 った原石を二次破砕機炕かけるすでの破砕，すなわら 通常 100 50 mm 程度まで破砝する場合を言い，二次

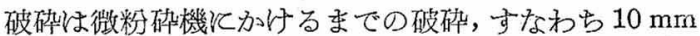
前後までの破砕のことを言っている・必要があれば二 次破研をさら反二段飞行う場合もまり，微粉碎を二段 飞行うことるむる。本日私が議題としている予備破碎 (Preliminary crushing) と结一次破砕，二次破碎の 総称である。

粉研理論を究明し, 粉砕仕事飞要する所要動力, 粉
砕機の能力等学算出するために, 約 80 年前にリッチ ンガー (Rittinger) によって唱えられたリッチンガー の法則以来，多くの研究者仙よって種々の公式が発表 されているが，被破砕物の状態は干種万様であって， また破砕機械内で被破砕物比加わ力の状態も極めて 複雑であるので，これを一般理論的に取扱うととは困 難であって，今日まで発表された数式と実際作業と は大きな誤差湆ある・したがって，われわれが破体機 の設計なり，破哱プラントの計画なりを行和うとする ときは，必ず実際の被破砕物によって若干の粉砕テス ト行った上でとれをやるととが安全である。

破研機内で被破砕物江加光られる力は压縮, 剪断, 引張り, 衝撃, 摩擦等であって, 機械の種類で相違す るが，これらの力が複合して加わる。従来多く使用さ れているジョウクラッシャ一，ジャイレートリークラ ッシャー,コーンクラッシャー,クラッシングロール， フェアモントクラッシャ一等は主として圧縮力によっ て破砕を行うるのであり, ハンマークラッシャー, イ ンペラーブレーカー等は主として衝撃力炕よって破碎 を行っている・主として圧縮力を利用した破碎機では その機構上，破确比（給鉱の平均粒度と破碎後の平均 粒度との比）を5 以上飞することは困難であり，通常 3 程度が経済的であるとされているが，インペラーブ レーカーでは破确比を 10 以上 50 程度にしても経済的

粒 度 $(\mathrm{cm})$

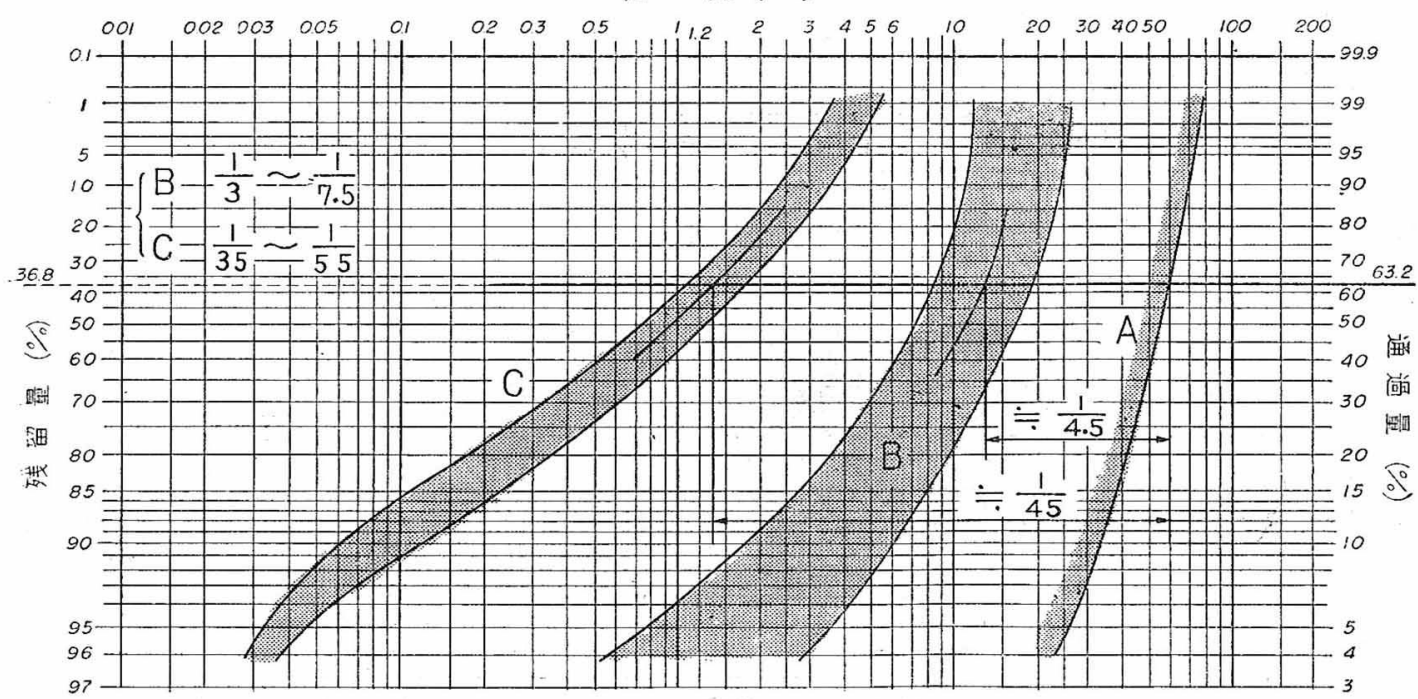

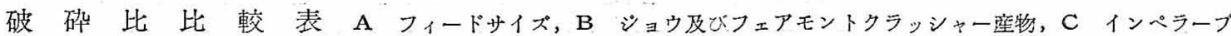
レーカ一应物

* 横山工業株式会社取締役工場長 
C 16

な破研を行うととが出来る・破破比が大きいととほ非 常な魅力であって, 破䂶プラントの建設費の低下, 破 碎コストの低下に大いに役立つ. 例えば石灰石の採掘 山で, 平均粒度 $600 \mathrm{~mm}$ 飞切出された原石を, 一次破 碎機としてジョウクラッシャーあるい惊つェアモント
弿協 65 [734] 1957 (2) 8

クラッシャーを使用したとき，その産物の平均粒度は: $130 \mathrm{~mm}$ 前後となり, これをセメント工場に送られて その全部を二次破砕機で処理しなければならない。一 次破碎機にインペラーブレーカーを使用すれば，その 産物の平均粒度は $13 \mathrm{~mm}$ 前後であり, 仮にミルフィ

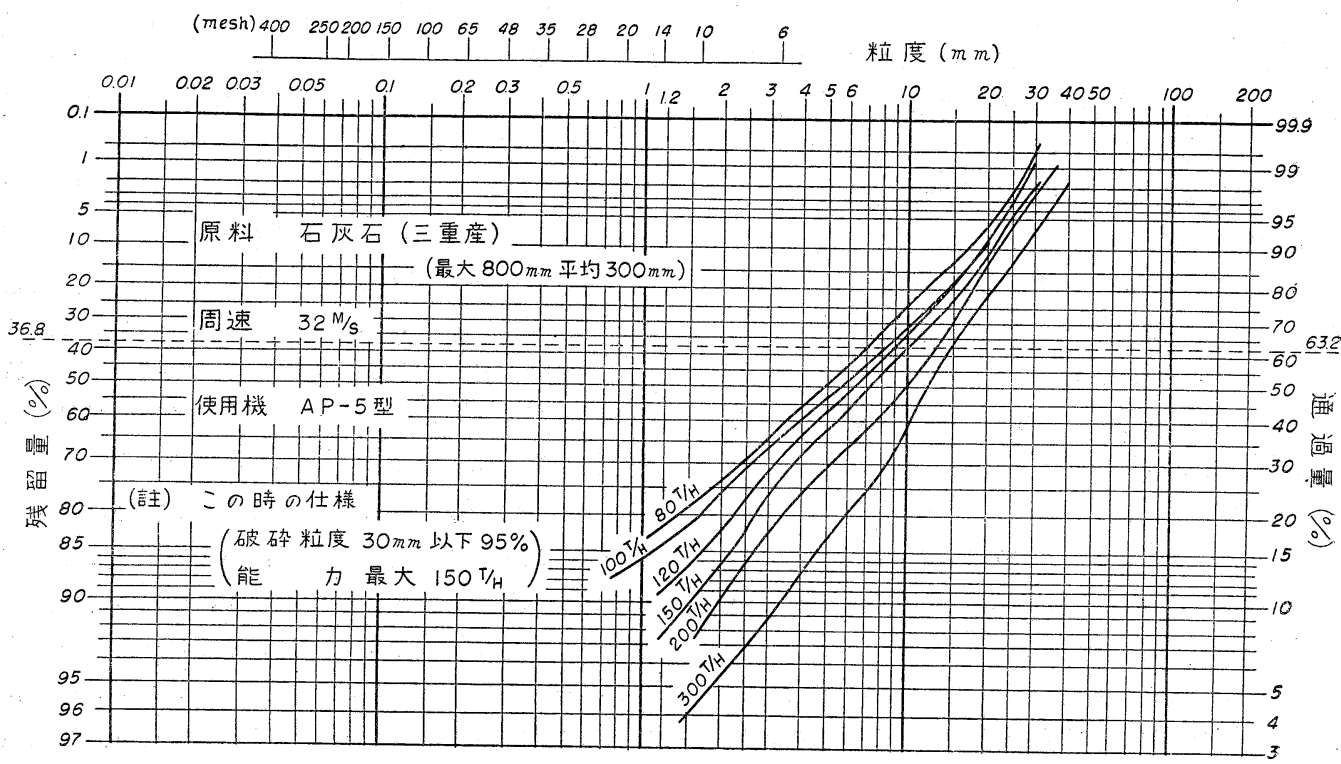

給鉱量の変化による破碎粒度の变化

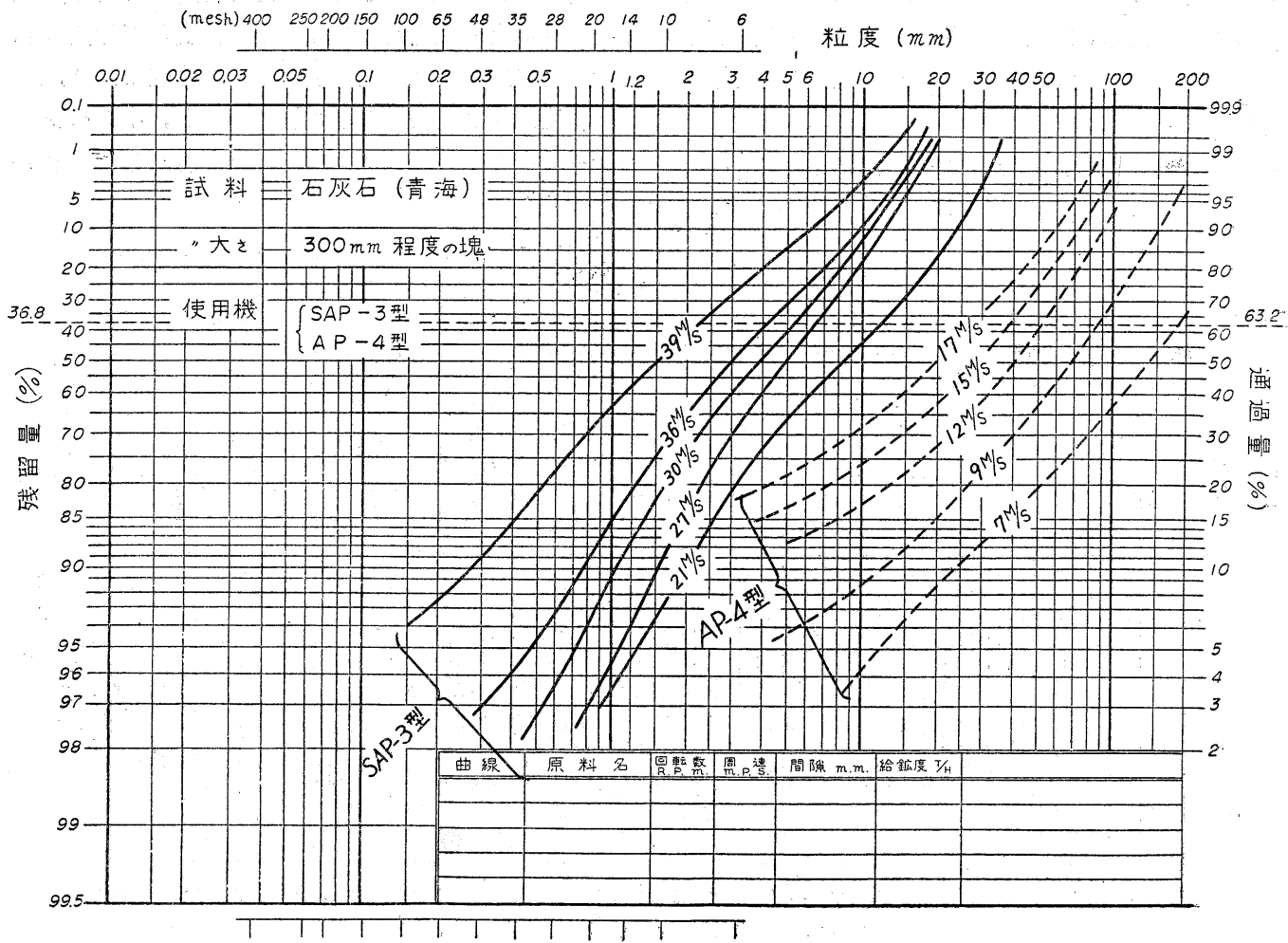

周速の变化による破碎粒度の影響 
ードを $6 \mathrm{~mm}$ 以下とすれば全量の約 $40 \%$ は二次破碎 を必要としないととになる (別表参照).

粉碎工程中最も費用のかかる部分は微粉碎である. 微粉砕機として現在一般飞使用されているボーミルあ るいはペッブルミルは, 御承知のようと動力損失が大 きく，またボール，ライニング等の消耗費も大きい。 ボールミルと置き変えられるべき微粉砕機が種々研究 されているが，石炭の微粉研汸ングローラー式のミ ルが使用されているのみで, クリンカーあるいはより
硬い石に対してはまだ新しい機械が出現していない。 横山工業でもノヴォローターミルというのを今春以来 研究しているが，硬い石付対してはまだ充分な自信が 持てない。如何なる微粉研機を使用するとしてる，ミ ルフィードの粒度を出来るだけ細かくすることによっ てミルの荷重を軽くしてやることが，粉础コストを低 下させるため有効であるととは一般の常識である が，とのためにはインペラーブレーカーは非常な成功 を納めている・例えば，セメントクリンカーの予倩破

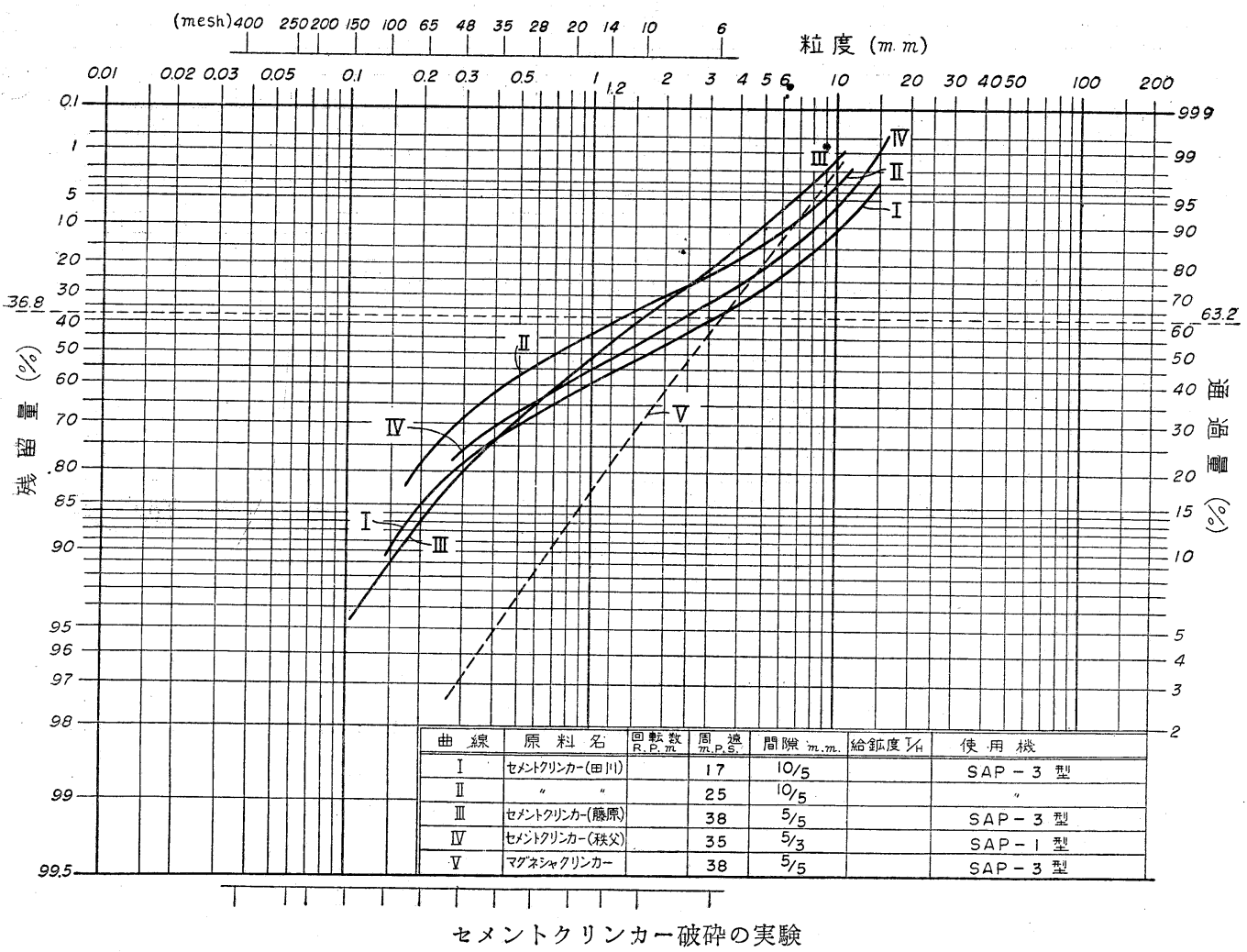

碚とインペラーブレーカーを使用し，ボールミルの所 要動力が約 10\% 減少し，ミルの処理量が 10\% 程度増 加した等の実績がある・ボールの消耗量も当然減少す るはずである・セメントクリンカーをインペラーブレ 一カーで破碎試験を行った時の粒度構成は別表を参照 願いたい。

煉瓦工場, 陶磁器工場で各種の原石破砕飞, 従来の フレットミルのかわりに, 最近インペラーブレーカー を多く使用されている。それは作業能率がはなはだし く改善され, 動力費, 人件費その他の点で経済的であ るためと考光られる.ある煉瓦工場での実験で，イン

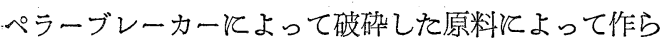
れた䍒瓦が，フレットミルで破砕した原料の煉瓦に比 較して気孔率が若干多く比重が軽く, したがって強度 が若干劣るという話を聞いたが，私が各種の原料のイ
ンペラーブレーカーによる破碎テストを行った結果か ら見ると,例外無くとの産物の粒形は cubical である。 偏平なるのや，細長いるのの率が極めて少いととが立 証されている。このために，コンクリートの骨材にそ の産物を使用した時，めるいは道路の敷石としてこれ を使用した場合に，他の方法で破碎した石を使ったる のよりる，より強いコンクリートあるいは道路が出来 るととが実験の結果立証されているので，煉瓦でも， 原料の粒度構成等にさらに御研究願えれ阮, よい結果 を得られるものと信じている。

インペラーブレーカーによる破碎で，最す困難な問 題は，粘結性の原料が粘結し易い水分 (15\%前後) を 持っている原料の破粋，拉よび或る種のはなはだしく 磨耗性の多い原料の破碎である。これと対してわれわ れは種々研究苦心しているが，まだ解決点と達してい 


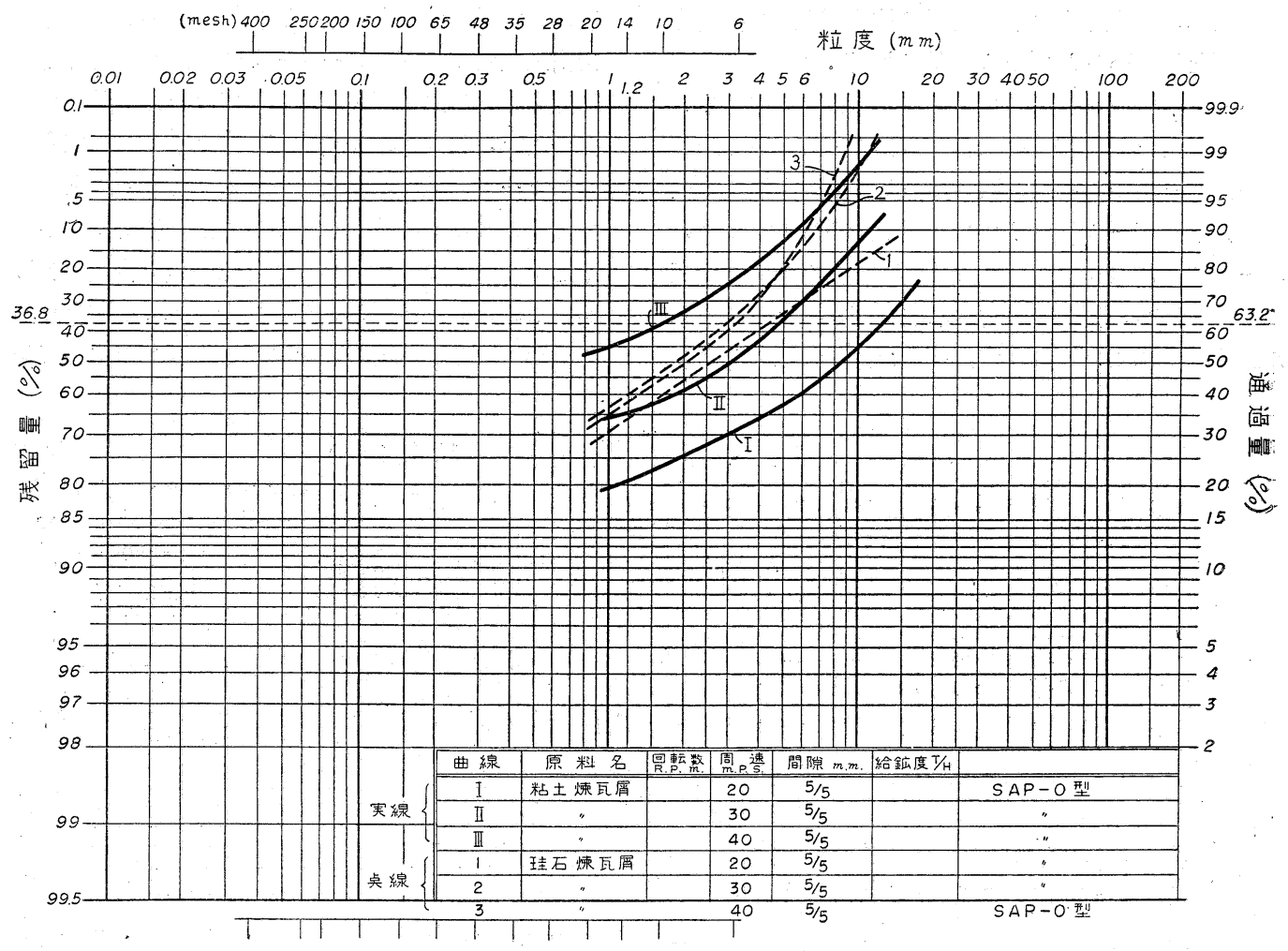

棟瓦屑破砕の実験

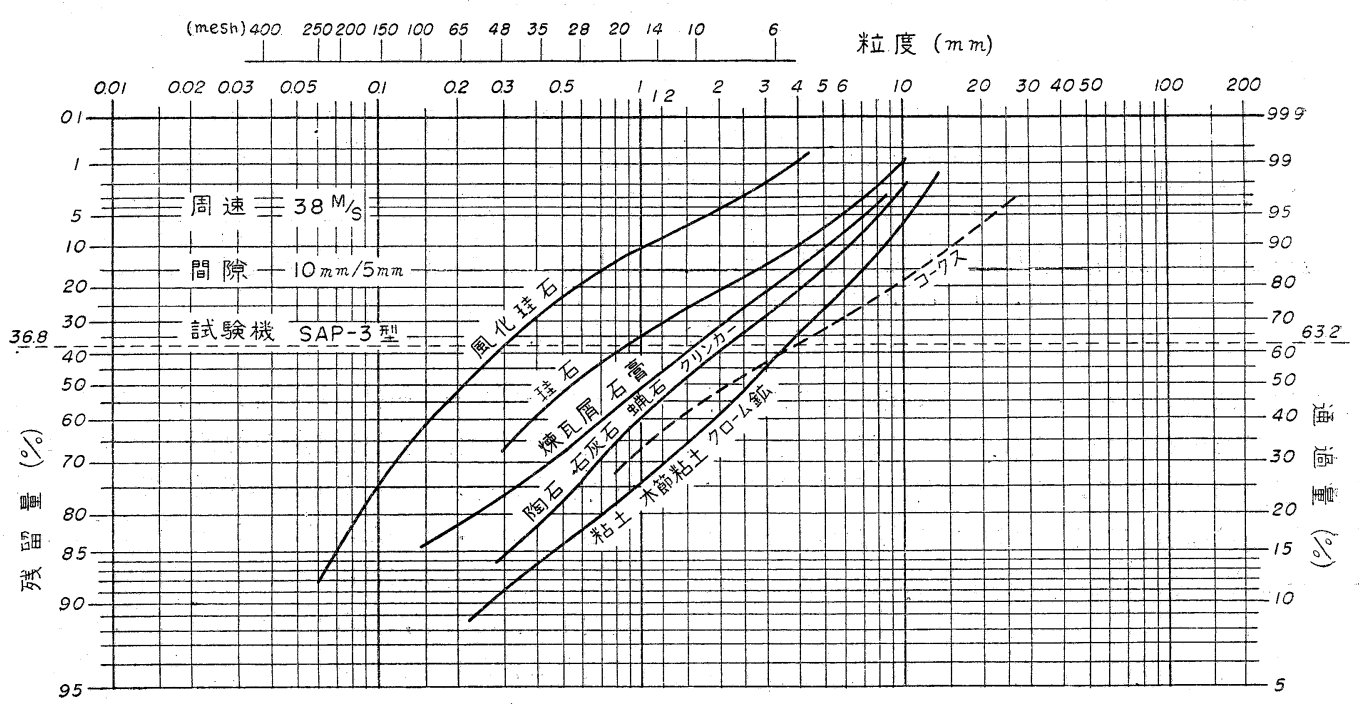

種々の材料を同一条件で破砕した場合

処理原石打整枝 1 組原石1下当りの 石西処理量(トン). 磿耗費 (円/トン)

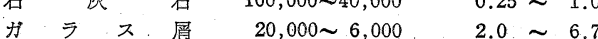
セメントクリンカー $\quad 8,000 \sim 1,500 \quad 5.0 \sim 27.0$ 珪石粘 土 $9,000 \sim 1,000 \quad 4.5 \sim 40.0$ 琶ルミナセメン石\}・1,000〜・120 4 $40.0 \sim 350.0$ (以上は型式SAP-3，ロータ一周速度 $36 \mathrm{~m} / \mathrm{sec}$ としての概数)
ない，付着の問題は或る程度鋳付き成長の時間を長引! かせるところへ来ている・最大の磨耗部分である打撃 板の磨耗費は大体左表の通りである。

はなはだ概略な話で, 充分意をつくさない点がある が，後刻御質問のときさらに括話し致したいと思う。 